\title{
Hepatorenal Effect of Single or Combined Moringa Olivera and Citrullus Colocynthis on Carbon Tetrachloride-Induced Injury in Spurge Dawely Rat
}

\author{
Mahmoud M. Elalfy ${ }^{1 *}$, Mona G. El-hadidy ${ }^{2}$, Amany Farag ${ }^{3}$, Ahmed A. Helmy ${ }^{4}$, \\ Fathy Radwan Ali ${ }^{1}$ \\ ${ }^{1}$ Forensic and toxicology dept., Mansoura University, Egypt \\ ${ }^{2}$ Medical physiology, faculty of medicine, Mansoura university \\ ${ }^{3}$ Histology department, Mansoura University, Egypt \\ ${ }^{4}$ Animal health research institute, Egypt
}

*Corresponding Author: Mahmoud M. Elalfy, Forensic and toxicology dept., Mansoura University, Egypt. Email: mahmoudelalfy@mans.edu.eg

\begin{abstract}
Medicinal plants consider a source of potential drug, adjuvant or protective agent against hepatorenal toxic chemicals. Liver and kidney diseases of different domestic animals resulted from different agents, antibiotics, plants toxin and even post vaccinal reaction. To better understand the potential of single or combined Moringa Olivera and Citrullus Colocynthis on carbon tetrachloride-induced injury in 70 male spurge dawely rat. Carbon tetrachloride at dose of $0.5 \mathrm{ml} / \mathrm{kg}$ (10\% in olive oil) for 8 weeks increased significantly level of creatinine while reduced significantly level of blood urea and non-significantly reduced level of total protein and albumin. Additionally, Moringa oleifera at dose of 250 and $500 \mathrm{mg} / \mathrm{kg}$ increased significantly level of glucose and total protein and albumin while retained creatinine to quite similar level to control group. Additionally, Citrullus colocynthis at dose of 12.5 and $25 \mathrm{mg} / \mathrm{kg}$ increased significantly level of blood urea and total protein while non-significantly increased of creatinine level and reduced significantly level of glucose. Kidney and liver of rats treated with combiend moringa oleifera at dose of $250 \mathrm{mg} / \mathrm{kg}$ and citrullus colocynthis at dose of $12.5 \mathrm{mg} / \mathrm{kg}$ with carbon tetrachloride at dose of $0.5 \mathrm{ml} / \mathrm{kg}(10 \%$ in olive oil) retain liver and kidney weight and structure to quite like control group even fail to retain creatinine level to basal level due to present of infiltrate or cast blocked renal tubules
\end{abstract}

Keywords: moringa Olivera, Citrullus colocynthis, hepatorenal toxicity, rats, SMA

\section{INTRODUCTION}

Liver and kidney diseases were reported in different domestic animals resulted from different agents, antibiotics, plants toxin and even post vaccinal reaction. Medicinal plant considers a source of potential drug or protective agent against hepatorenal toxic chemicals.

The pharmacological and nutritive potentials of extract of Moringa Oleifera (Biswas et al. (2012) and Citrullus colocynthis (Dallak 2011) has been frequent studied, they aimed to provide a chance for the future scientists to discover a new drug molecule for curing animal or human diseases. The potent pharmacological effects of this medicinal plant as it possesses antiinflammatory, antioxidant, antimicrobial, antihepatorenal toxicity (Nanjappaiah and Hugar 2012, Sachan ,2012, Kumar et al. 2013, Olatosin et al. ,2014 and Mansour et al. 2014), anti-cancer, antiulcer (Patel et al. 2012), hypotensive, and anti-hyperlipidimic activities (Ouédraogo et al., 2011, Saalu et al. 2012 and Yadav et al. 2013).

The antioxidant and hypolipidemic effects of Citrullus Colocynthis extract in alloxan induced diabetic rats investigated by Dallak (2011) and the analysis showed significant decreases in phospholipids, total cholesterol, triglycerides, free fatty acids levels of diabetic rats treated with Citrullus Colocynthis as compared to diabetic untreated rats, Colocynthis had a potent antioxidant and hypolipidemic effects in alloxan induced diabetic rats (Benariba et al., 2013). Additionally, Shokrzadeh et al. (2013) investigated the protective effect of Citrullus Colocynthis extract against genotoxicity in bone marrow induced by cyclophosphamide which was evaluated by micronucleus assay as an index of chromosomal damaged occurred through its antioxidant feature (Nessa and Khan 2014). Also, 
the protective effect of Citrullus Colocynthis oil and olive oil against oxidative stress induced by cadmium (Amamou et al. (2015) or paracetamol induced hepatotoxicity in the liver of rats Vakiloddin et al. (2015).

The rationale of this study to provide the hepatorenal effect of single or combined treatment of Moringa and Citrullus in Spurge dawely rat.

\section{Material AND Methods}

\subsection{Medicinal Plants}

\subsubsection{Preparation of Moringa Oleifera Leaves Ethanolic Extract}

Moringa Oleifera leaves ethanolic extract was prepared and described earlier (Fathy et al., 2017).

\subsubsection{Preparation of Citrullus Colocynthis Ethanolic Extract}

Citrullus Colocynthis fruits ethanolic extract was prepared and described earlier (mahmoud et al., 2019)

\subsubsection{Pharmacological Evaluation (Determin- ation of Maximum Ultraviolet Absorbance

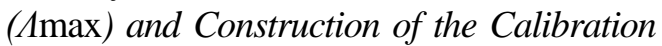 Curves of both Plants Extracts)}

The maximum ultraviolet absorbance $\left(\lambda_{\max }\right)$ and construction of the calibration curves of both plants extracts were carried out inside the pharmaceutics laboratory, faculty of pharmacy, Mansoura University was done to confirm that each $1 \mathrm{gm}$ of the obtained extracts contained an exact $1 \mathrm{gm}$ of the plants extract substance to avoid the miss calculation of the administrated doses of each plant (mahmoud et al., 2019).

\subsection{Animals and Treatments}

70 males' spurge dawely rats weighted from 130 to $150 \mathrm{gm}$ were kept in the laboratory under constant conditions of temperature $(24 \pm 2 \mathrm{C})$ for at least one week before and through the experimental work, being maintained on a standard diet and water were available ad libitum. The animals were maintained in accordance with the guidelines prescribed by the Faculty of Science and the study was approved by the Animal Ethics Committee of the University of Mansoura, Egypt.

The experimental rats were divided into seven groups:

Group 1: Animals were fed on the standard diet and were served as control group.

Group 2: Rats were injected intraperitoneally with $1.0 \mathrm{ml} / \mathrm{kg}$ b.w. of $10 \% \mathrm{CCl}_{4}$ dissolved in olive oil twice a week for eight weeks (Abdelaziz and Ali, 2014).

Group 3: Rats were injected with $1.0 \mathrm{ml} / \mathrm{kg}$ b.w. of $10 \% \quad \mathrm{CCl}_{4}$ followed by oral administration of $250 \mathrm{mg} / \mathrm{kg}$ b.w. ethanolic extract of Moringa oleifera (Fathy et al., 2017), twice a week for eight weeks.

Group 4: Rats were injected with $1.0 \mathrm{ml} / \mathrm{kg}$ b.w. of $10 \% \mathrm{CCl}_{4}$ followed by oral administration of 500 $\mathrm{mg} / \mathrm{kg}$ b.w. ethanolic extract of Moringa oleifera, twice a week for eight weeks.

Group5: Rats were injected with $1.0 \mathrm{ml} / \mathrm{kg}$ b.w. of $10 \% \mathrm{CCl}_{4}$ followed by oral administration of 12.5 $\mathrm{mg} / \mathrm{kg}$ b.w. (1/8of the LD50) ethanolic extract of Citrullus Colocynthis, twice a week for eight weeks (Mahmoud at al., 2019).

Group 6: Rats were injected with $1.0 \mathrm{ml} / \mathrm{kg}$ b.w. of $10 \% \mathrm{CCl}_{4}$ followed by oral administration of 25 $\mathrm{mg} / \mathrm{kg}$ b.w. (1/4 of the LD50) ethanolic extract of Citrullus Colocynthis, twice a week for eight weeks.

Group7: Rats were injected with $1.0 \mathrm{ml} / \mathrm{kg}$ b.w. followed by oral administration of $12.5 \mathrm{mg} / \mathrm{kg}$ b.w. ethanolic extract of Citrullus Colocynthis and $250 \mathrm{mg} / \mathrm{kg}$ b.w. ethanolic extract of Moringa Oleifera, twice a week for eight weeks.

\subsection{Histopathological Examination}

The treated animals and their controls were sacrificed by decapitation after 8 weeks of treatment. Their kidneys were removed and fixed in $10 \%$ neutral formalin. Fixed materials were embedded in paraffin wax and sections of 4 micrometer thickness were cut. Slides were stained with hematoxylin and eosin for histological examination.

\subsection{Immunohistochemical Localization of A- SMA}

Fixed kidney tissue was embedded in paraffin and then sectioned at $4-5 \mathrm{~mm}$. The sections were deparaffinized, rehydrated, and heated (using a microwave oven) to boiling $0.01 \mathrm{M}$ citrate buffer ( $\mathrm{pH}$ 6.0). Upon boiling, the sections were subsequently heated (low heat setting) for an additional $15 \mathrm{~min}$. The sections were then blocked in $1.5 \%$ normal serum for 10 $\mathrm{min}$ at room temperature. The following antisera (Santa Cruz Biotechnology, Inc., Santa Cruz, CA, USA) were used SMA. The kidney sections were incubated with antisera overnight at room temperature using the following dilutions for 1:200. then washed 3 times and incubate for secondary antibody Immunoreactivity (as 
identified by brown color) to the respective protein was then visualized using the DAKO Staining System following the manufacturer's protocol. Sections were counterstained with Mayer's hematoxylin. The sections were then photographed using digital camera.

\subsection{Biochemical Assays}

For biochemical study serum were obtained by centrifugation of the blood samples and stored at $20^{\circ} \mathrm{C}$ until assayed for the biochemical parameters as following methods; Creatinine (Bowers et al., 1980), urea (Patton and Crouch, 1977), glucose (Kaplan et al., 1984), total protein (Vassault et al., 1986), albumin (Doumas et al., 1981) and globulin levels (Doumas et al., 1972).

\subsection{Statistical Analysis}

The obtained data in this study were statistically analyzed for variance by One Way ANOVA
(Snedecor et al., 1989) by using computerized SPSS program (1996) version 13.0.

\section{Results}

Both plants treated group reduced body weight non-significantly when compared with ccl4 treated as control positive for nephropathy. Notably, group treated with both Moringa oleifera and Citrullus colocynthis retain body weight to normal level.

In the current study, kidney and liver weight was reduced significantly in group treated with only ccl4 or combined with Moringa oleifera at doses of 250 or $500 \mathrm{mg} / \mathrm{kg}$. But Moringa oleifera and Citrullus colocynthis treated group retain kidney weight slightly little than normal level. Moreover, Renal or liver to body weight ratio of all treated group was reduced nonsignificantly when compared with control group.

Table1. Shows Effect of single treatment of Moringa oleifera and Citrullus colocynthis on body weight, kidney weight and renal to body weight ratio when given with carbon tetrachloride

\begin{tabular}{|l|l|l|l|}
\hline & \multicolumn{1}{|c|}{ Body weight } & \multicolumn{1}{c|}{ Kidney weight } & \multicolumn{1}{c|}{ Renal to body weight ratio } \\
\hline Group 1 & $260 \pm 12.4$ & $1.9 \pm 0.07$ & $0.74 \pm 0.01$ \\
\hline Group 2 & $240 \pm 19$ & $1.68^{\mathrm{b} 1,7} \pm 0.09$ & $0.71 \pm 0.03$ \\
\hline Group 3 & $206^{\mathrm{b} 1} \pm 12$ & $1.44^{\mathrm{b} 1,7} \pm 0.09$ & $0.69 \pm 0.03$ \\
\hline Group 4 & $214^{\mathrm{b} 1,2} \pm 20$ & $1.5^{\mathrm{b} 1,7} \pm 0.1$ & $0.71 \pm 0.02$ \\
\hline Group5 & $218^{\mathrm{b} 1,2} \pm 9.0$ & $1.60^{\mathrm{b} 1,7} \pm 0.80$ & $0.74 \pm 0.03$ \\
\hline Group 6 & $197^{\mathrm{b} 1} \pm 11.0$ & $1.30^{\mathrm{b} 1,7} \pm 0.80$ & $0.71 \pm 0.03$ \\
\hline Group 7 & $267 \pm 15$ & $1.8 \pm 0.1$ & $0.69 \pm 0.02$ \\
\hline
\end{tabular}

B1,2 significantly at $\leq 0.05$

Both group treated with Citrullus colocynthis at 12.5 and $25 \mathrm{mg} / \mathrm{kg}$ reduced body weight of treated male rats significantly when compared with control group while only treated group at dose of $25 \mathrm{mg} / \mathrm{kg}$ reduced significantly when compared with carbon tetrachloride treated animals as control positive for nephropathy. Notably, group treated with both Moringa oleifera and Citrullus colocynthis retain body weight to normal level. In the current study, kidney weight was reduced significantly in group treated with only carbon tetrachloride or combined with Citrullus colocynthis at doses of 12.5 and $25 \mathrm{mg} / \mathrm{kg}$. But Moringa oleifera and Citrullus colocynthis treated group retain kidney weight slightly little than normal level. Moreover, group treated with $25 \mathrm{mg} / \mathrm{kg}$ of Citrullus colocynthis retain Renal to body weight ratio to basal level while other treated groups was reduced non-significantly when compared with control group.
In the current study, carbon tetrachloride increased significantly level of creatinine while reduced significantly level of blood urea and non-significantly reduced level of total protein, albumin. Additionally, Moringa oleifera at dose of 250 and $500 \mathrm{mg} / \mathrm{kg}$ increased significantly level of glucose and total protein and albumin while retained creatinine to quite similar level to control group. Additionally, Citrullus colocynthis at dose of 12.5 and $25 \mathrm{mg} / \mathrm{kg}$ increased significantly level of blood urea and total protein while non-significantly increased of creatinine. Moreover, Citrullus colocynthis reduced significantly reduced level of glucose. In contrast, combined treatment of Moringa oleifera at dose of $250 \mathrm{mg} / \mathrm{kg}$ and Citrullus colocynthis at $12.5 \mathrm{mg} / \mathrm{kg}$ increased significantly level of creatinine, glucose and total protein. 
Hepatorenal Effect of Single or Combined Moringa Olivera and Citrullus Colocynthis on Carbon Tetrachloride-Induced Injury in Spurge Dawely Rat

Table2. Effect of single treatment of Moringa oleifera and Citrullus colocynthis on serum biochemical parameters on induced nephropathy model by carbon tetrachloride.

\begin{tabular}{|l|l|l|l|l|l|l|l|}
\hline & $\begin{array}{l}\text { Glucose } \\
\text { mg/dL }\end{array}$ & $\begin{array}{l}\text { Creatinine } \\
\text { mg/dL }\end{array}$ & $\begin{array}{l}\text { Urea } \\
\text { mg/dL }\end{array}$ & BUN:Creatinine(BCR) & $\begin{array}{l}\text { T.P } \\
\text { mg/dL }\end{array}$ & $\begin{array}{l}\text { Albumin } \\
\text { g/dL }\end{array}$ & $\begin{array}{l}\text { Globulin } \\
\text { g/dl }\end{array}$ \\
\hline Gr.1 & $220 \pm 6.4$ & $0.5 \pm 0.03$ & $50.6 \pm 3.9$ & 101.2 & $7 \pm 0.29$ & $3.9 \pm 0.1$ & $\mathbf{3 . 1} \pm 0.2$ \\
\hline Gr.2 & $224 \pm 1.6$ & $0.64^{\mathrm{b} 1} \pm 0.02$ & $36.8^{\mathrm{b} 1} \pm 1.8$ & $57.5^{\mathrm{b} 1}$ & $6.8 \pm 0.6$ & $3.86 \pm 0.24$ & $\mathbf{3 . 0 6} \pm 0.1$ \\
\hline Gr.3 & $278^{\mathrm{b} 1} \pm 2.2$ & $0.55 \pm 0.05$ & $40.7 \pm 2.1$ & $74^{\mathrm{b} 1,2}$ & $8.1^{\mathrm{bl}} \pm 0.2$ & $4.4 \pm 0.37$ & $\mathbf{3 . 7} \pm 0.1$ \\
\hline Gr.4 & $282^{\mathrm{b} 1} \pm 2.4$ & $0.57 \pm 0.02$ & $46.5 \pm 4.6$ & $81.5^{\mathrm{b} 1,2,3}$ & $9.9^{\mathrm{b} 1} \pm 0.7$ & $4.6 \pm 0.34$ & $\mathbf{5 . 4} 4^{1,2,3} \pm 0.3$ \\
\hline Gr.5 & $206 \pm 1.7$ & $0.77 \mathrm{~b}^{\mathrm{b} 1} \pm 0.06$ & $82.7^{1,2,3,4} \pm 5.1$ & $107.4^{\mathrm{b} 1,2,3}$ & $8.7^{\mathrm{b}^{\mathrm{b}} \pm 0.2}$ & $3.2 \pm 0.09$ & $5.5^{\mathrm{b} 1,2,3} \pm 0.2$ \\
\hline Gr.6 & $209 \pm 1.2$ & $0.67^{\mathrm{b} 1} \pm 0.02$ & $79.7^{\mathrm{b} 1,2,3,4} \pm 6.2$ & $118.9^{\mathrm{b} 1,2,3}$ & $7.8^{\mathrm{b}^{\mathrm{b}} \pm 0.6}$ & $3.27 \pm 0.47$ & $4.6^{\mathrm{b}^{\mathrm{b}}, 2,3} \pm 0.2$ \\
\hline Gr.7 & $251^{\mathrm{b} 1} \pm 2.5$ & $0.88^{1,2,3,4,5,6} \pm 0.06$ & $57^{\mathrm{b} 2,5,6} \pm 3.6$ & 101.2 & $9.1^{\mathrm{b}^{\mathrm{b}} \pm 1.3}$ & $3^{\mathrm{b} 1} \pm 0.24$ & $6.1^{1,2,3} \pm 0.2$ \\
\hline
\end{tabular}

B1,2 significantly at $\leq 0.05$

BUN: Creatinine ratio (BCR) is interesting tools for Glomerular filtration function of kidney, but only used in patient rather than experimental research, in the current study carbon tetrachloride reduce significantly the BCR level when compared to control group. While Citrullus colocynthis and combined treatments improve the BCR quite to normal than single treatment of moringa Olivera

Notably, nephropathy model induced by carbon tetra chloride at dose $0.5 \mathrm{ml} / \mathrm{kg}$ of $10 \%$ (v/v) show interstitial fibrosis, mild inflammatory infiltrate and thick-walled blood vessels. Kidney of rat treated with moringa olifera at dose of 250 $\mathrm{mg} / \mathrm{kg}$ combined with carbon tetrachloride show focal interstitial fibrosis and chronic inflammation. Kidney of rat treated with Moringa oleifera at dose of $250 \mathrm{mg} / \mathrm{kg}$ combined with carbon tetrachloride show moderate staining collagen stained with mallory trichrome stain. Moreover, kidney of rats treated with Moringa oleifera at dose of $500 \mathrm{mg} / \mathrm{kg}$ combined with carbon tetrachloride show moderate focal interstitial fibrosis stained with mallory trichrome stain.
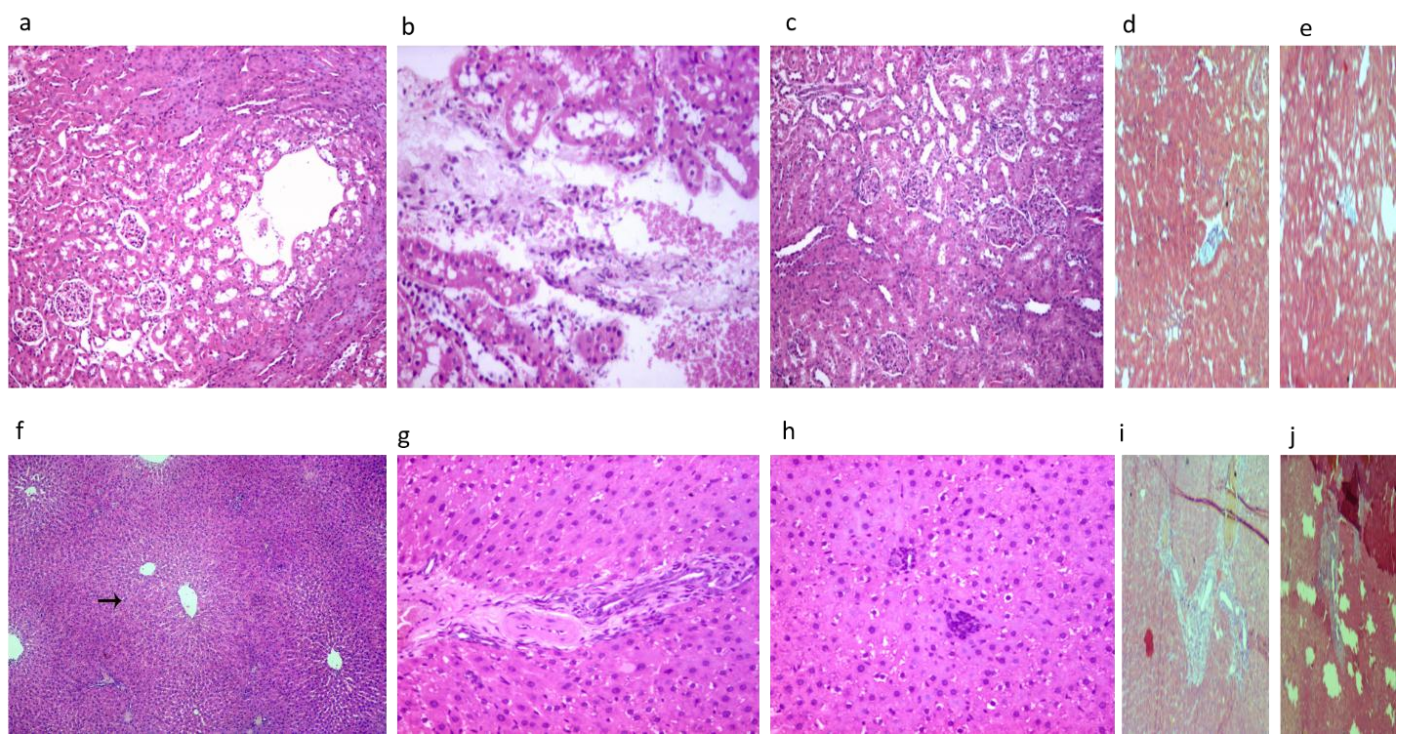

Fig1a. normal kidney artecture, $\boldsymbol{b}$. kidney of rats treated with ccl4 shown interstitial fibrosis, mild inflammatory infiltrate and thick walled blood vessels. $c$. focal interstitial fibrosis and chronic inflammation (Moringa Olivera $250 \mathrm{mg} / \mathrm{kg}$ ). $\boldsymbol{d}$, e collagen deposition in kidney evidence by Mallory trichrome (Moringa Olivera 250mg/kg, $500 \mathrm{mg} / \mathrm{kg}$ respectively). $f$. normal liver histology. g. massive liver fibrosis (ccl4 treatment) $\boldsymbol{h}$. focal lytic necrosis ((Moringa Olivera $250 \mathrm{mg} / \mathrm{kg})$. $\boldsymbol{i}, \boldsymbol{j}$ collagen deposition in liver evidence by Mallory trichrome (Moringa Olivera $250 \mathrm{mg} / \mathrm{kg}, 500 \mathrm{mg} / \mathrm{kg}$ respectively).

Citrullus colocynthis at dose of $12.5 \mathrm{mg} / \mathrm{kg}$ show moderate improvement of kidney architecture while rats treated with Citrullus colocynthis at dose of $12.5 \mathrm{mg} / \mathrm{kg}$ combined with carbon tetrachloride show focal staining of

ARC Journal of Animal and Veterinary Sciences collagen with mallory trichrome stain while kidney of rats treated with Citrullus colocynthis at dose of $25 \mathrm{mg} / \mathrm{kg}$ combined with carbon tetrachloride show reduction of focal staining of collagen with mallory trichrome stain.

Page $\mid 4$ 


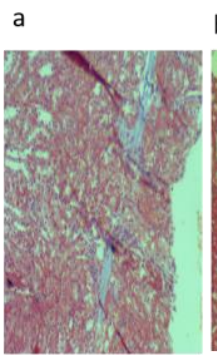

d
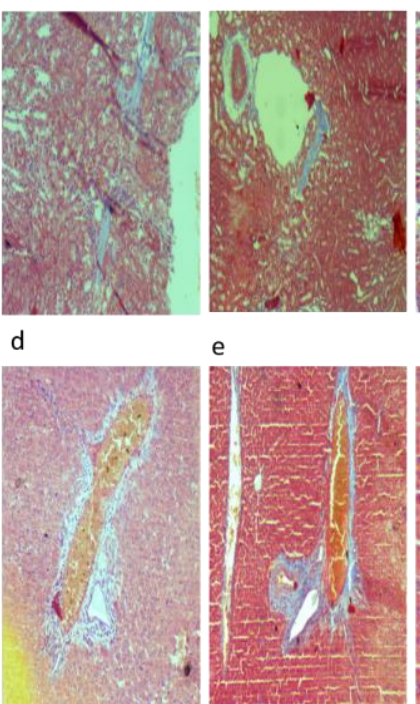

C
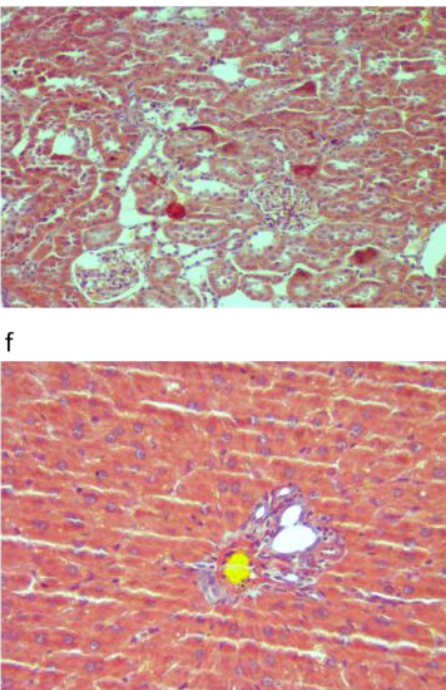

Fig2. $\boldsymbol{a}, \boldsymbol{b}$ collagen deposition in kidney evidence by Mallory trichrome (Citrullus $12.5 \mathrm{mg} / \mathrm{kg}, 25 \mathrm{mg} / \mathrm{kg}$ respectively). c. renal tissue show complete absence of collagen evidence by Mallory trichrome stain in combined treatments of moth moringa and Citrullus against ccl4 treatment. $\boldsymbol{d}$, e collagen deposition in liver evidence by Mallory trichrome (Citrullus $12.5 \mathrm{mg} / \mathrm{kg}, 25 \mathrm{mg} / \mathrm{kg}$ respectively). $f$. few leucocytic infiltration in combined treatments of moth moringa and Citrullus against ccl4 treatment.

Interestingly, kidney of rats treated with both show moderate reaction against SMA Moringa oleifera at dose of $250 \mathrm{mg} / \mathrm{kg}$ and Monoclonal antibody. While moringa Olivera Citrullus colocynthis at dose of $12.5 \mathrm{mg} / \mathrm{kg}$ treatment at of $500 \mathrm{mg} / \mathrm{kg}$ (fig 3 e) and (fig $3 \mathrm{f}$ ) combined with carbon tetrachloride show colocynthis at dose of $25 \mathrm{mg} / \mathrm{kg}$ shown little negative staining of mallory trichrome stain or staining of SMA. Finally, combination treatment no evidence of collagen fiber infiltration.

Notably, moderate reduction of S.M.A treatment of both moringa oleifera at dose of $250 \mathrm{mg} / \mathrm{kg}$ of moringa oleifera at dose of $250 \mathrm{mg} / \mathrm{kg}$ and Citrullus colocynthis at dose of $12,5 \mathrm{mg} / \mathrm{kg}$ (fig $3 \mathrm{~g})$ reduction of S.M.A staining reaction. and Citrullus colocynthis at dose of $12,5 \mathrm{mg} / \mathrm{kg}$
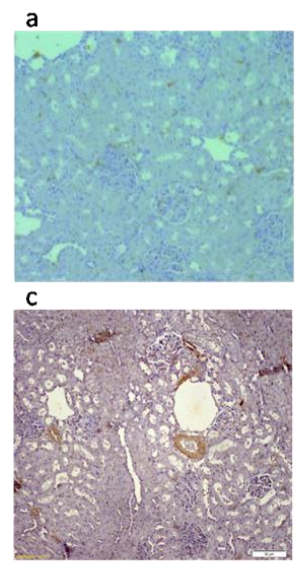

e

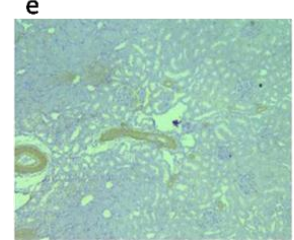



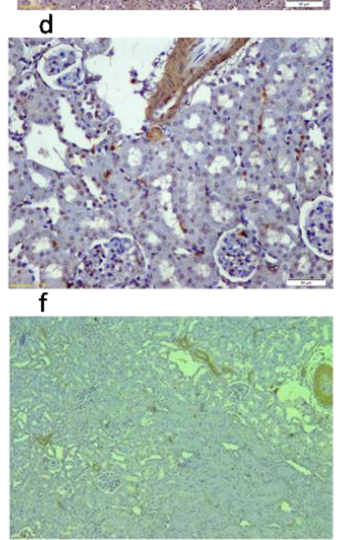

g

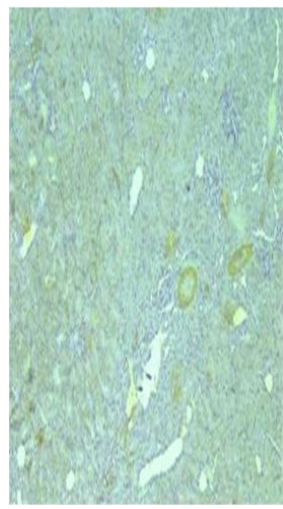

Fig3. show level of SMA (smooth muscle actin), (a) Negative staining of SMA in treated negative control group, (b) Massive staining of SMA induced by carbon tetrachloride, (c) moderate reduction of SMA by treatment of moringa oleifera at dose of $250 \mathrm{mg} / \mathrm{kg}$, (d) little staining of SMA by moringa olefera treatment at of $500 \mathrm{mg} / \mathrm{kg}$ (e) Citrullus colocynthis at dose of $12,5 \mathrm{mg} / \mathrm{kg}$ shown little SMA expression $(\mathrm{f})$ moderate SMA expression by treatment of Citrullus colocynthis at dose of $25 \mathrm{mg} / \mathrm{kg}(\mathrm{g})$ reduction of SMA staining by combination treatment of moringa oleifera at dose of $250 \mathrm{mg} / \mathrm{kg}$ and Citrullus colocynthis at dose of $12,5 \mathrm{mg} / \mathrm{kg}$. 
a

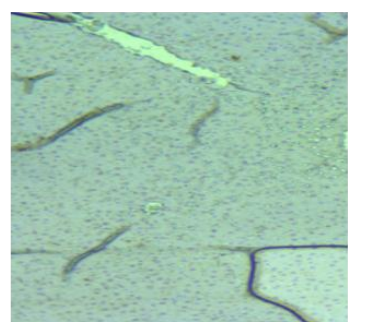

b

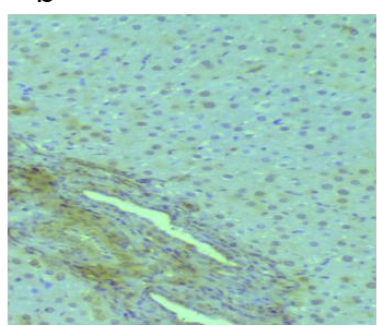

$c$

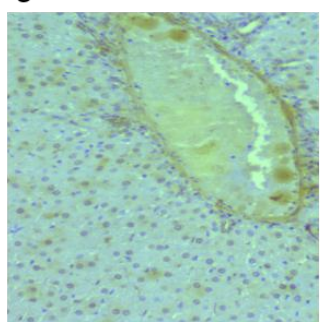

d

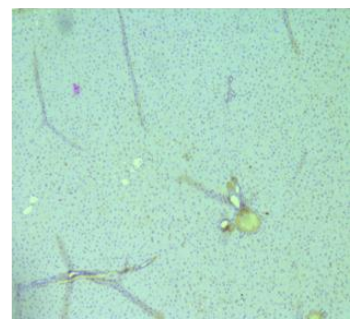

Fig4. a negative control. $\boldsymbol{b}$, c postive SMA staining due to either moringa $500 \mathrm{mg} / \mathrm{kg}$ of citrullus $25 \mathrm{mg} / \mathrm{k}$ while d. show combined treatment of both plant show minimal SMA staining reaction.

\section{DISCUSSION}

Many agents like heavy metal, drugs, pesticide, environmental agents and poisonous plant consider hazard factors for hepatorenal toxicity. Moreover, hepatorenal toxicity can occur due to another disease like diabetes enhanced agents, so our world scientist still do the best effort to search new medical cure for diseases affect liver and kidney with advanced technology.

In the present study, both Moringa oleifera and Citrullus colocynthis when each was given alone along with carbon tetrachloride reduced body weight when compared with carbon tetrachloride treated as control positive for nephropathy or control group. Notably, group treated with both Moringa oleifera and Citrullus colocynthis along with carbon tetrachloride retain body weight to normal level. This result agrees with Adewole (2007) who found that the administration of carbon tetrachloride significantly decreased body weight when compared with the control.

Kidney weight was reduced significantly in group treated with only carbon tetrachloride or combined with Moringa oleifera at doses of 250 or $500 \mathrm{mg} / \mathrm{kg}$. But Moringa oleifera and Citrullus colocynthis treated group retain kidney weight slightly little than normal level. This result disagrees with Adewole (2007) who found that carbon tetrachloride significantly increased kidney weight. Additionally, Soufane et al (2013) who found that group sacrificed after 10 days of treatment of Citrullus colocynthis has presented a significant reduction in the relative weights of the kidney when compared to control group. In the current study, carbon tetrachloride increased significantly levels of creatinine and reduced significantly levels of blood urea and non-significantly reduced level of total protein and albumin.

In the current study, Moringa oleifera at dose of 250 and $500 \mathrm{mg} / \mathrm{kg}$ when given with carbon tetrachloride increased significantly levels of glucose, total protein and albumin while retained creatinine to quite similar level to control group. These results agree with Ouédraogo et al. (2011) who found that the Moringa oleifera at dose of 150 and $300 \mathrm{mg} / \mathrm{kg}$ plus gentamicin treated groups reduced serum urea and creatinine levels. On pathological examinations, kidney of intoxicated rabbits' groups which received Moringa oleifera extract showed reparative tendencies. Combined treatment of Moringa oleifera and gentamicin group showed a highly significant depletion in lipid peroxidation (LPO) level. Moreover AlMalki1 and El Rabey (2015) found that treatment of diabetic rats with 50 or $100 \mathrm{mg} / \mathrm{kg}$ Moringa oleifera seeds powder ameliorated the levels of renal parameters approaching the negative control values and restored the normal histology of both kidney and pancreas compared with that of the diabetic positive control group.

Notably in the presented study, combined treatment of Moringa oleifera at dose of 250 $\mathrm{mg} / \mathrm{kg}$ and Citrullus colocynthis at $12.5 \mathrm{mg} / \mathrm{kg}$ when combined with carbon tetrachloride increased significantly levels of creatinine, glucose, total protein. Moreover, in other study reported by Omayma et al. (2013) who found that Citrullus colocynthis administration to diabetic rat, improved hyperglycemia, impaired kidney, dyslipidemia and attenuates the states of antioxidant enzyme and oxidative stress induced by diabetes mellitus. Additionally, El-Baky and Amin (2011) reported that the medicinal plant Citrullus colocynthis fruit may have protective effect on the kidney functions and tissues. As it may play a role in prevent nephropathy as one of micro vascular complications of diabetes mellitus. Notably, Efiong $\mathbf{E} \mathbf{E}$ and Ebong $\mathbf{P} \mathbf{E}$ (2014) recorded that the efficacy of the combined extracts of Ocimum Gratissimum and Moringa Oleifera ameliorates diabetic nephropathy at better manner in a synergistic 
pattern when compared with the single extracts and standard drugs insulin and glibenclamide.

Interestingly, Kidney and liver of rats treated with both moringa oleifera at dose of $250 \mathrm{mg} / \mathrm{kg}$ and citrullus colocynthis at dose of $12.5 \mathrm{mg} / \mathrm{kg}$ combined with carbon tetrachloride retain renal weight and renal histology to quite like control group even fail to retain creatinine level to basal level due to present of infiltrate or cast blocked renal tubules. These results agree with Iwara et al, (2013) investigated the protective effect of combined extracts of Moringa oleifera and Vernonia Amygdalina on STZ induced kidney damage in rats. Also, Rajan et al. (2016) who found that the combination of Moringa oleifera seeds and cannabidiol was more effective than treatment with single constituents in the antiinflammatory, anti-apoptotic and ant oxidative effects.

In the current study, moringa oleifera at 2 successful doses reduced collagen infiltration by mallory trichrom stain when treated with carbon tetrachloride. These results agree partially with Al-Malki and El Rabey (2015) who found that treated group with two low doses of Moringa oleifera seed powder $(50$ and $100 \mathrm{mg} / \mathrm{kg}$ body weight) in the diet restored the normal histology of both kidney when combined treated with streptozotocin

\section{CONClusions}

Administration of both plants together has been failed to decrease creatinine level while improve BUN/creatinine ratio and improved the kidney and liver structure in carbon tetrachloride model of toxicity.

\section{REFERENCES}

[1] Abdelaziz DH, Ali SA. The protective effect of Phoenix dactylifera L. seeds against CCl4induced hepatotoxicity in rats. $\mathrm{J}$ Ethnopharmacol. 2014 8;155(1):736-43.

[2] Adewole Stephen O., Salako Abdulkadir A., Doherty Oladepo W. and Naicker Thajasvarie E. (2007) effect of Melatonin on Carbon tetrachloride Induced Kidney Injury in Wistar Rats. African Journal of Biomedical Research, Vol. 10153 - 16.

[3] $\mathrm{Ali}^{1}$ Al-Malki Abdulrahman L. and El Rabey Haddad A. (2015): The Antidiabetic Effect of Low Doses of Moringa oleifera Lam. Seeds on Streptozotocin Induced Diabetes and Diabetic Nephropathy in Male Rats BioMed Research International Volume 2015 Article ID 381040, 13 pages.

ARC Journal of Animal and Veterinary Sciences
[4] Amamou F., Nemmiche S., Meziane R. K., Didi A., Yazit S. M., \& Chabane-Sari D. (2015): Protective effect of olive oil and colocynth oil against cadmium-induced oxidative stress in the liver of Wistar rats. Food and Chemical Toxicology, 78, 177-184.

[5] Bowers LD, Wong ET (1980): a colorimetric method for determination of serum creatinine level. Clin. Chem 26:555.

[6] Dallak M. (2013): In vivo, hypolipidemic and antioxidant effects of Citrullus colocynthis pulp extract in alloxan-induced diabetic rats. African Journal of Biotechnology, 10(48), 9898-9903.

[7] Doumas, B.T., Bayso, D.D., Carter, R.J., Peter, T., Schaffer, R., 1981. Determination of serum albumin. Clin. Chem. 27, 1642. Franklin, N.M.,

[8] Doumas, B.T., Biggs, H.G., 1972. Determination of serum globulin. In: Cooper (Ed.), In: Standard Methods of Clinical Chemistry, Vol. 7. Academic Press, New York.

[9] Efiong E. E. and Ebong P. E. (2014): Ocimum Gratissimum and Moringa Oleifera Ameliorates Diabetic Nephropathy in a Synergistic Manner Similar to Insulin. Journal of Pharmaceutical, Chemical and Biological Sciences, Jun-August 2(2):158-165.

[10] El-Baky Atef E. Abd and Amin Hatem K. (2011): effect of citrullus colocynthis in ameliorate the oxidative stress and nephropathy in diabetic experimental rats International Journal of Pharmaceutical Studies and Research/Vol. II/ Issue II/April-June, /1-10.

[11] Fathy R. Ali, Mahmoud M. Elalfy, Ahmed A. Helmy and Ahmed M. Elgamal. Effect of Egyptian Moringa Oleifera Lam. on blood hematology, serum biochemical parameters and lipid profile with special reference to kidney function in albino rats. Nat Sci 2017;15(9):3642]

[12] Iwara I. A., Otu E. A., Efiong E. E., Igile G. O., Mgbeje B. A. I., Ebong P. E. (2013): Evaluation of the Nephroprotective Effects of Combined Extracts of Vernonia amygdalina and Moringa oleifera in Diabetes Induced Kidney Injury in Albino Wistar Rats. Sch. J. App. Med. Sci., 1(6):881-886.

[13] Kaplan, L. A. (1984): A colorimetric method for determination of glucose. Clin Chem the C.V. MosbyCO. St Louis. Toronto. Princeton 1032-1036.

[14] Kumar E., K.N. Harsha, S. Shaik, N.N. Rao N.G., Babu (2013): Evaluation of in Vitro Antioxidant Activity and in Vivo Hepatoprotective Activity Of Moringa Oleifera Seeds Extract Against Ethanol Induced Liver Damage In Wistar Rats. IOSR Journal of Pharmacy 
[15] Mahmoud M. Elalfy ${ }^{1}$, Amany Farag ${ }^{2}$, Ahmed A. Helmy ${ }^{3}$, Zein Elaabdeen Metwaly ${ }^{3}$, and Fathy Radwan Hematological, Biochemical and Cytotoxic Effect of Ethanolic Raw Extract of Egyptian Citrullus Colocynthis In Sprague Dawley Rat. Enzyme Engineering journal volume 8, issue 1, 2019

[16] Mansour H. H., Abd El Azeem M. G. and Ismael N.E (2014): Protective Effect of Moringa oleifera on $\gamma$ - Radiation-Induced Hepatotoxicity and Nephrotoxicity in Rats. AJPCT [2][4]495-508.

[17] Olatosin T. M., Akinduko D. S. and Uche C. Z. (2014): Antioxidant capacity of Moringa oleifera seed oil against $\mathrm{CCl}_{4}$ induced hepatocellular lipid peroxidation in wistar albino rats. Euro. J. Exp. Bio., 4(1):514-518.

[18] Omayma A.R., Abou Zaid, Khalid, M. Fararh, Aliaa and H.Ali (2013): biochemical effect of citrullus colocynthis in experimental diabetes mellitus in rats. Benha veterinary medical journal, VOL. 25, NO. 1:218-227

[19] Ouédraogo M., Lamien-Sanou A., Ramdé N., Ouédraogo A. S., ZongoS.P., Goumbri O., Duez P., Guissou P. I. (2011): Protective effect of Moringa oleifera leaves against gentamicininduced nephrotoxicity in rabbits. Exp. Toxicol. Pathol. 2013 Mar; 65(3):335-9.

[20] Patel Ankur, Sharma Prasanna, CS Shastry (2012): Antiulcerogenic activity of Moringa oleifera root extract against ethanol-induced gastric ulcer in rats, international journal of pharmaceutical and chemical

[21] Patton, C.J. and Crouch, S.R. (1977): Enzymatic determination of urea. Anal. Chem., 49: 464469 AnalysisChemistry Journal, 49:464-469
[22] Rajan, Thangavelu Soundara, Sabrina Giacoppo, Renato Iori, Gina Rosalinda De Nicola, Gianpaolo Grassi, Federica Pollastro, Placido Bramanti, and Emanuela Mazzon (2016): Anti-inflammatory and Antioxidant Effects of a Combination of Cannabidiol and Moringin in LPS-stimulated Macrophages. Fitoterapia 112:104-15.

[23] Saalu L. \& Ogunlade B. (2012): The hepatoprotective potentials of Moringa oleifera leaf extract on alcohol-induced hepato-toxicity in wistar rat. American Journal of Biotechnology and Molecular Sciences, 2(1), 6-14.

[24] Sachan D. (2012): Effect of the Ethanolic Extract of Moringa oleifera Linn. Plant on Ethylene Glycol Induced Lithiatic Albino Rats. IJTPR

[25] Snedecor, George W. and Cochran, William G. (1989): Statistical Methods, Eighth Edition, Iowa State University Press

[26] Soufane S., A. Bedda, N. Mahdeb, A. Bouzidi (2013): Acute Toxicity study on Citrullus colocynthis fruit methanol extract in Albino rats Journal of Applied Pharmaceutical Science, Vol. 3 (06), 088-093

[27] Vakiloddin S., N. Fuloria, S. Fuloria, S. A. Dhanaraj, K. Balaji, and S. Karupiah. (2017): Evidences of Hepatoprotective and Antioxidant Effect of Citrullus Colocynthis Fruits in Paracetamol Induced Hepatotoxicity. Pak. J. Pharm. Sci., Vol.28, No.3, 951-957.

[28] Yadav J., Sharma S. K., Singh L., Singh T. (2013): AN OVERVIEW ON MORINGA OLEIFERA: A POTENTIAL MEDICINAL HERB. Journal of Drug Discovery and Therapeutics 1 (7), 100-105.

Citation: Mahmoud M. Elalfy, Mona G. El-hadidy, Amany Farag, Ahmed A. Helmy, Fathy Radwan Ali. Hepatorenal Effect of Single or Combined Moringa Olivera and Citrullus Colocynthis on Carbon Tetrachloride-Induced Injury in Spurge Dawely Rat. ARC Journal of Animal and Veterinary Sciences. 2019; 5(1):1-8. doi: dx.doi.org/10.20431/2455-2518.0501001.

Copyright: () 2019 Authors. This is an open-access article distributed under the terms of the Creative Commons Attribution License, which permits unrestricted use, distribution, and reproduction in any medium, provided the original author and source are credited. 